\title{
Analysis of carbon dioxide, water vapour and energy fluxes over an Indian teak mixed deciduous forest for winter and summer months using eddy covariance technique
}

\author{
Chandra Shekhar Jha ${ }^{1}$, Kiran Chand Thumaty ${ }^{1, *}$, Suraj Reddy Rodda ${ }^{1}$, \\ AJIT SONAKIA ${ }^{2}$ and VINAY KUMAR DADHWAL ${ }^{1}$ \\ ${ }^{1}$ National Remote Sensing Centre (ISRO), Balanagar, Hyderabad 500 037, India. \\ ${ }^{2}$ Madhya Pradesh Forest Department, Satpura Bhawan, Bhopal 462 004, India. \\ *Corresponding author.e-mail: trkchand@gmail.com
}

In the present study, we report initial results on analysis of carbon dioxide $\left(\mathrm{CO}_{2}\right)$, water vapour $\left(\mathrm{H}_{2} \mathrm{O}\right)$, and energy fluxes (sensible and latent heat flux) over teak mixed deciduous forests of Madhya Pradesh, central India, during winter (November 2011 and January 2012) and summer (February-May 2012) seasons using eddy covariance flux tower datasets. During the study period, continuous fast response measurements of $\mathrm{CO}_{2}, \mathrm{H}_{2} \mathrm{O}$ and heat fluxes above the canopy were carried out at $10 \mathrm{~Hz}$ and averaged for 30 minutes. Concurrently, slow response measurements of meteorological parameters are also being carried out. Diurnal and seasonal variations of $\mathrm{CO}_{2}, \mathrm{H}_{2} \mathrm{O}$ and heat fluxes were analysed and correlated with the meteorological variables. The study showed strong influence of leaf off and on scenario on the $\mathrm{CO}_{2}, \mathrm{H}_{2} \mathrm{O}$ and energy fluxes due to prevalence of deciduous vegetation type in the study area. Maximum amount of $\mathrm{CO}_{2}$ was sequestered for photosynthesis during winter (monthly mean of $-25 \mu \mathrm{mol} / \mathrm{m}^{2} / \mathrm{s}$ ) compared to summer (monthly mean of $-2 \mu \mathrm{mol} / \mathrm{m}^{2} / \mathrm{s}$ ). Energy flux analysis (weekly mean) showed more energy being portioned into latent heat during winter $\left(668 \mathrm{~W} / \mathrm{m}^{2}\right)$ and sensible heat during summer $\left(718 \mathrm{~W} / \mathrm{m}^{2}\right)$.

\section{Introduction}

Measurements of $\mathrm{CO}_{2}$, water vapour and heat fluxes across the vegetation-atmosphere interface are essential to understand different processes controlling the carbon storage in the vegetative systems. Extensive research in eddy covariance has mostly addressed the following: (1) to monitor the Net Ecosystem Exchange (NEE) of $\mathrm{CO}_{2}$ and (2) to understand various processes that affect the fluxes. A review of the past research on estimating the NEE suggests that there has been a notable shift in the technological approaches of measuring the carbon fluxes at leaf level (Field et al. 1982; Collatz et al. 1991), whole plant level (Denmead et al. 1993), inventory studies of Biomass (Clark et al. 2001) to the most recently and reliably used eddy covariance based methods to measure ecosystem carbon exchange (Running et al. 1999; Canadell et al. 2000; Geider et al. 2001). The advantages in using eddy covariance technique is that it is scale-appropriate, measures direct $\mathrm{CO}_{2}$ flux over the canopy-atmosphere interface using micro-meteorological theory (Baldocchi et al. 1988; Verma 1990), provides information over tower footprint (Schmid 1994) and can be achieved across different time scales (Wofsy et al. 1993; Baldocchi et al. 2001).

Keywords. Eddy covariance; Indian deciduous forests; $\mathrm{CO}_{2}$ flux; heat flux. 
Earlier studies have used eddy covariance technique for measuring $\mathrm{CO}_{2}$ exchange date back to the early 1970s (Desjardins and Lemon 1974) which used slow-time response sensors. Over time, fast response infrared gas analysers, which can sense $\mathrm{CO}_{2}$ flux at the rate of $10 \mathrm{~Hz}$ are being operationally used from mid 1980s till date both in agriculture (Ohtaki 1984; Desjardins 1985; Anderson and Verma 1986) and in natural ecosystems (Wesely et al. 1983; Verma et al. 1986, 1989; Fan et al. 1990; Kim and Verma 1990; Wofsy et al. 1993). Currently a network of more than 550 eddy covariance based flux towers operate for continuous measurements of $\mathrm{CO}_{2}$ flux across the globe as part of regional flux tower networks, viz., Ameriflux, Euroflux, AsiaFlux, etc.

Considerable amount of studies were carried out using eddy covariance based flux towers in deciduous systems outside India. Analysis of seasonal and inter-annual variability of energy fluxes over a broad leaved temperate deciduous forest has been carried out (Wilson and Baldocchi 2000). Study on eddy covariance measurements for estimation of NEE and GPP over cool temperate deciduous forests of Japan was carried out in relation with air temperature, absorbed PAR, light use efficiency and leaf area index (Saigusa et al. 2002). Similarly, a study has been carried out to understand the temporal variability of light use efficiency (LUE) using simultaneous measurements of eddy flux towerbased $\mathrm{CO}_{2}$ flux, fAPAR and satellite based NDVI over a deciduous forest in USA (Jenkins et al. 2007). A study on surface energy balance components with special emphasis on storage heat flux across forest-atmosphere interface has been carried out in temperate deciduous forests of south-central Indiana, USA (Oliphant et al. 2004). Garrity et al. 2011 studied the phenophases using 11 years of NEE data with reference to multiple phenology satellite data sources. Similarly, upscaling of FluxNet measurements using remote sensing data derived land surface temperature (LST) and land surface phenology (LSP) to address carbon uptake phenology (CUP) for spring and autumn seasons in temperate and boreal deciduous forests was also carried out (Gonsamo et al. 2012). Modelling of gross and net ecosystem exchange of $\mathrm{CO}_{2}$ to study seasonal and inter-annual variability for cool temperate broad leaved forests of Japan using process based model was attempted by Ito et al. (2005).

Though the above-listed studies have been carried out outside Indian continent, this study is one of the first few in India, in which eddy flux tower datasets have been analysed in a natural ecosystem. Results of this study represent initial understanding of deciduous forest system of central India.

\subsection{Objectives}

The present study is carried out as part of the 'Soil and Vegetation-Atmosphere Flux (SVAF)' subproject of the 'National Carbon Project - NCP' an Indian Space Research Organization-Geosphere Biosphere Programme's (ISRO-GBP) initiative, which is envisaged to assess the country's total carbon pool and fluxes using ground-based measurements and satellite remote sensing datasets. As part of the SVAF sub-project of the NCP, network of micro-meteorological flux towers are being established across representative natural and man-made ecosystems across India to continuously measure NEE of $\mathrm{CO}_{2}$ and other GHGs of interest.

The objective of the present study is to measure and analyse the $\mathrm{CO}_{2}, \mathrm{H}_{2} \mathrm{O}$ and heat flux over mixed deciduous forests of central Indian region and understand its relationship with vegetation and meteorological controls.

\section{Study area and site description}

Figure 1(a and b) shows the location map of the flux tower and ground photograph of the tower respectively. The tower is located at $21^{\circ} 51^{\prime}-$ $46.84^{\prime \prime} \mathrm{N}$ latitude and $77^{\circ} 25^{\prime} 33.67^{\prime \prime} \mathrm{E}$ longitude and $507 \mathrm{~m}$ above sea level, inside mixed deciduous forests of Betul district, Madhya Pradesh, India. Location of the tower had been selected based on the NCP-SVAF strategy to commission a network of flux towers which were to represent major natural and man-made ecosystems across India. Forests of the study area represent one of the major forest types in central Indian region dominated by teak. Other parameters considered during the site selection process for the present tower are flat terrain around the footprint of the tower and almost uniform forest stand height which are important and account for minimizing the errors in eddy covariance based computations of the tower datasets.

Major tree species occurring in the study area are Tectona grandis, Lagerostromia parviflora, Miliusa Tomentosa and Diospyros melanoxylon whose average stand height is about $22 \mathrm{~m}$. The average winter and summer temperatures of the study area are $20^{\circ} \mathrm{C}$ and $34^{\circ} \mathrm{C}$, respectively and average annual rainfall is about $1016 \mathrm{~mm}$. The site description of tower location is given in table 1 .

\section{Methodology}

The average height of the canopy is $22 \mathrm{~m}$ in the study area and the eddy flux tower has been set up at a height of $34 \mathrm{~m}$. The tower has been erected during October 2011 and data has been 


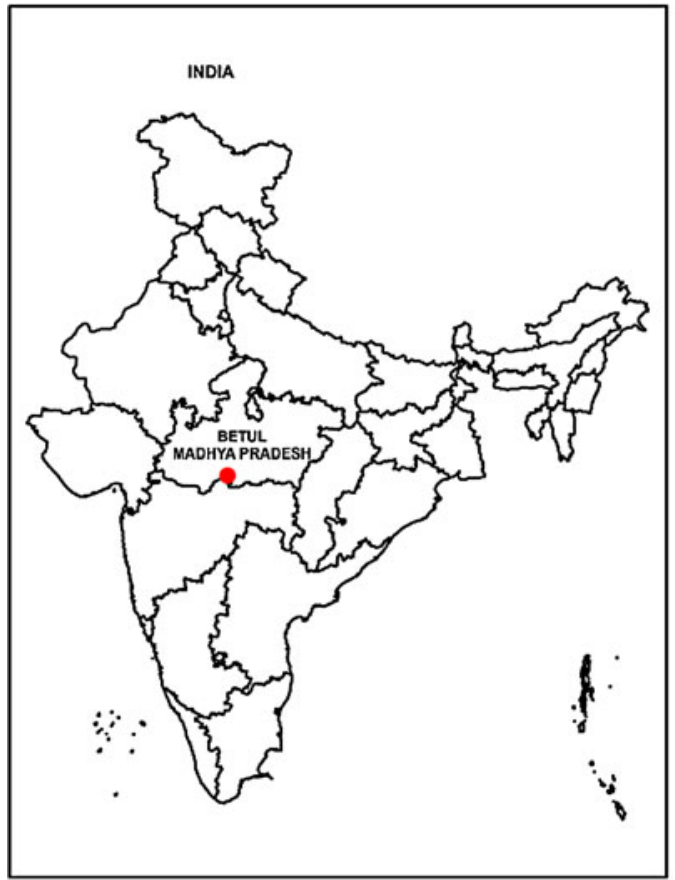

(a)

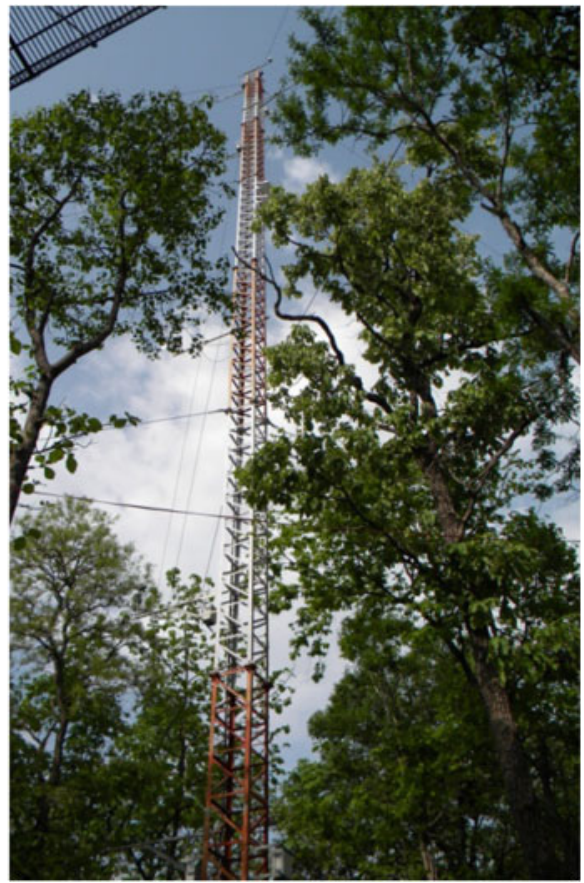

(b)

Figure 1. (a) Location map of the study area and (b) ground photograph of $34 \mathrm{~m}$ tower.

Table 1. Site description.

\begin{tabular}{ll}
\hline Item & \multicolumn{1}{c}{ Description } \\
\hline Site name & Sukhwan, Betul, Madhya Pradesh \\
Country & India \\
Location & Betul, Madhya Pradesh, India \\
Latitude and longitude & $21^{\circ} 51^{\prime} 46.84^{\prime \prime} \mathrm{N}, 77^{\circ} 25^{\prime} 33.67^{\prime \prime} \mathrm{E}(507 \mathrm{~m}$ ASL) \\
$\quad$ (first decimal of second precision), & \\
elevation (geographic coordinates, & \\
surveying method) & \\
Slope & $<5^{\circ}$ \\
Terrain type & Flat \\
Area & 176 ha \\
Fetch & $400-1000 \mathrm{~m}$ \\
Climate (Köppen climate classification) & Tropical moist climates \\
& $($ hot summer-cool winter) (As) \\
Mean annual air temperature & $27^{\circ} \mathrm{C}$ \\
Mean annual precipitation & 1016 mm \\
Vegetation type & Teak mixed moist deciduous forest \\
Dominant species (overstory) & Tectona grandis (Teak) \\
Dominant species (understory) & Miliusa tomentosa \\
Canopy height & $22 \mathrm{~m}$ \\
Age & About 50 years old \\
\hline
\end{tabular}

continuously measured and analysed. The tower is equipped with slow and fast response sensors at varied heights above and below canopy. The list of slow and fast sensors used and parameters measured is given in tables 2 and 3, respectively.
Continuous fast responses of $\mathrm{CO}_{2}, \mathrm{H}_{2} \mathrm{O}$ and heat fluxes above the canopy were measured at $10 \mathrm{~Hz}$ frequency using eddy covariance based open path Infrared Gas Analyser (IRGA-LICOR 7500) and 3D Ultrasonic Anemometer (RM Young 
Table 2. Slow response sensors/measurements.

\begin{tabular}{lll}
\hline Observation items & \multicolumn{1}{c}{ Levels/depth } & \multicolumn{1}{c}{ Instrument } \\
\hline Global solar radiation (downwelling) & $28 \mathrm{~m}$ & CMP 6 \\
Long-wave radiation (upwelling) & $28 \mathrm{~m}$ & CGR-03 \\
Air temperature & $32,28,16,8,4,2 \mathrm{~m}$ & Rotoronic Hygroclips S3 \\
Humidity & $32,28,16,8,4,2 \mathrm{~m}$ & Rotoronic Hygroclips S3 \\
Soil temperature & & Komoline KDS 037 \\
Soil water content & $32,28,16,8,4,2 \mathrm{~m}$ & RM Young 5103 \\
Wind speed & $32,28,16,8,4,2 \mathrm{~m}$ & RM Young 5103 \\
Wind direction & $28,2 \mathrm{~m}$ & Komoline KDS 021 \\
Barometric pressure & $32 \mathrm{~m}$ & RM Young 52203 \\
Precipitation & &
\end{tabular}

Table 3. Fast response sensors/measurements.

\begin{tabular}{ll}
\hline Item & \multicolumn{1}{c}{ Description } \\
\hline System & Open path system \\
Wind speed & 3-axis Ultrasonic anemometer (RM Young 81000) \\
Air temperature & 3-axis Ultrasonic anemometer (RM Young 81000) \\
Water vapour & Open path analysers (IR Hygrometer LI-COR LI 7500) \\
$\mathrm{CO}_{2}$ & Open path analysers (IR Hygrometer LI-COR LI 7500) \\
Measurement height & $28,2 \mathrm{~m}$ \\
Sampling frequency & $10 \mathrm{~Hz}$ \\
Averaging time & $30 \mathrm{~min}$ \\
Data logger & Campbell (CR 3000) \\
Data storage & $2 \mathrm{~GB}$ Data card \\
Original data & Raw data \\
(raw data or statistics) & \\
\hline
\end{tabular}

81000) and averaged for 30 minutes. Similarly, slow response measurements of meteorological parameters, viz., wind speed, wind direction, air temperature, relative humidity and incoming solar radiation are being carried out and average for every 30 minutes was recorded in the datalogger. Flux computations from raw data were carried out using Eddypro Express post-processing software (version 4.0, LI-COR, USA). The software processing involved corrections for compensation of time lag between sonic anemometer and gas analyser, frequency response, air density fluctuations and statistical tests for raw time series data, viz., spike count/removal, amplitude resolution, drop outs, absolute limits, skewness and kurtosis. In the present analysis, only flux variations above the canopy are considered. Continuous measurements of the slow and fast response sensors were analysed and presented.

\subsection{Theory of eddy covariance measurements}

In the present study, theoretical considerations for eddy covariance measurements and flux computations are assumed based on Burba and Anderson (2007) as follows:

The basic principle of eddy covariance measurements is that vertical flux can be calculated as covariance between concentration of the entity of interest (e.g., $\mathrm{CO}_{2}, \mathrm{CH}_{4}$ ) and vertical wind speed in the eddies.

In Turbulent flow, vertical flux can be expressed as:

$$
F=\overline{\rho_{a} w s},
$$

where $F$ is the flux, $\rho_{a}$ is the air density, $w$ is the vertical wind speed and $s$ is the mixing ratio of gas of interest. The important assumption for EC method is that terrain should be homogeneous and flat (i.e., density fluctuations and the mean vertical flow are assumed negligible). These assumptions define the eddy flux approximately equal to the product of mean air density $\rho_{a}$ and the mean covariance between the deviations in instantaneous vertical wind speed $\left(w^{\prime}\right)$ and mixing ratio $\left(s^{\prime}\right)$.

$$
F=\overline{\rho_{a} w^{\prime} s^{\prime}} .
$$

Accordingly, $\mathrm{CO}_{2}$ flux is presented as the mean covariance between deviations in instantaneous 
vertical wind speed and density of $\mathrm{CO}_{2}$ in the air and expressed as:

$$
F_{c}=\overline{w^{\prime} \rho_{c}^{\prime}} .
$$

Sensible heat flux is equal to the mean air density multiplied by the covariance between deviations in instantaneous vertical wind speed and temperature and is expressed as:

$$
H=\rho_{a} C_{p} \overline{w^{\prime} T^{\prime}} .
$$

Latent heat flux is computed in a similar manner and expressed as:

$$
L E=\lambda \frac{M_{w} / M_{a}}{P} \rho_{a} \overline{w^{\prime} e^{\prime}}
$$

where $C_{p}$ is the specific heat of air at constant pressure, $M_{w}$ and $M_{a}$ are molar masses of water and air, respectively.

\section{Results and discussions}

Figure 2(a) shows diurnal variations of $\mathrm{CO}_{2}$ flux (monthly mean) and figure 2(b) shows seasonal variations of $\mathrm{CO}_{2}$ (weekly mean) above the canopy level. Diurnal and seasonal variations of $\mathrm{CO}_{2}$ flux showed a maximum value of $-25 \mu \mathrm{mol} / \mathrm{m}^{2} / \mathrm{s}$ during noon hours (1100-1200 hrs) in winter due to peak photosynthetic activity. The $\mathrm{CO}_{2}$ assimilation gradually decreased with the progress of

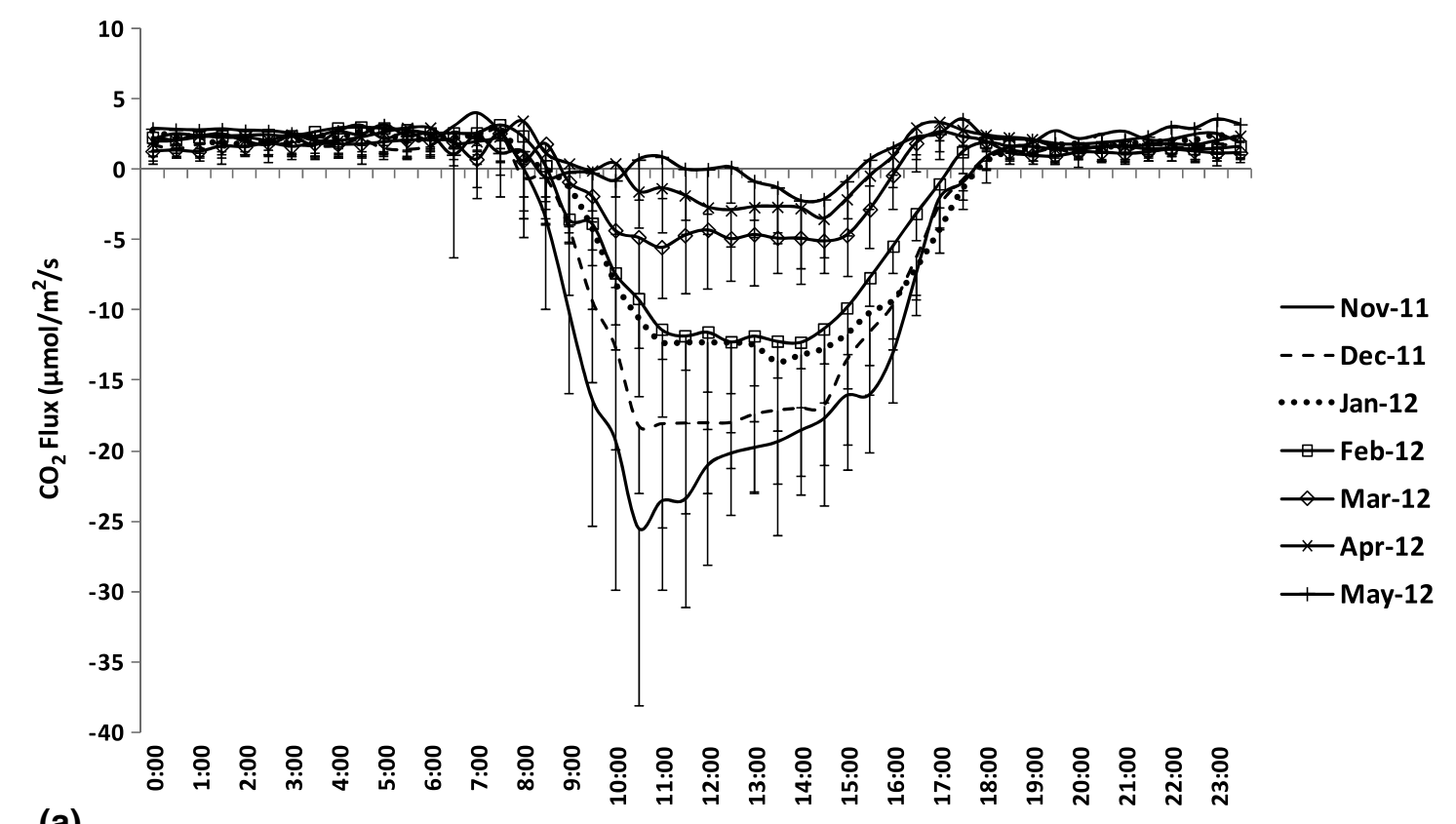

(a)

Time of the day (Hours)

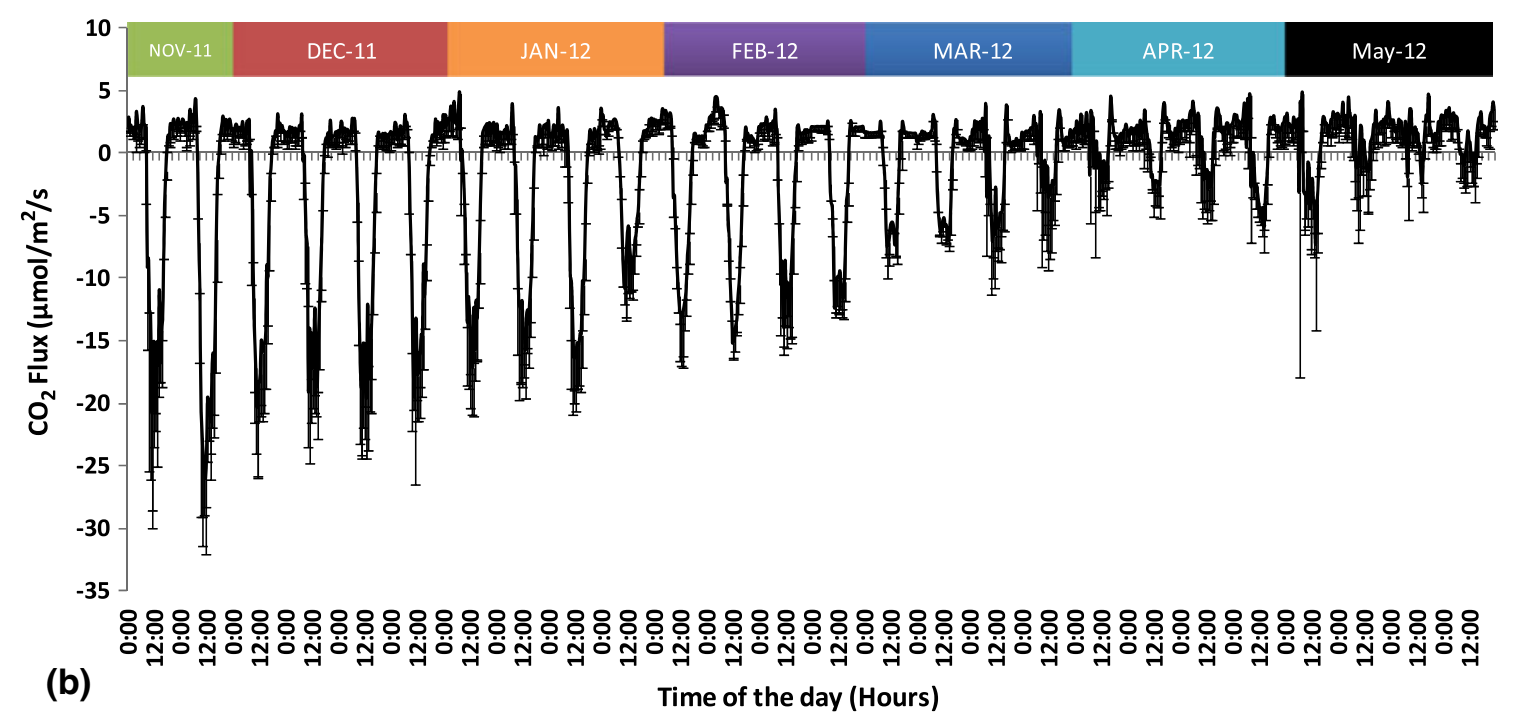

Figure 2. (a) Diurnal variations (monthly mean) in $\mathrm{CO}_{2}$ flux with \pm 1 standard deviation and (b) $\mathrm{CO}_{2}$ flux variations (weekly mean) from November 2011 to May 2012 with \pm 1 standard deviation. 
dry season towards May with maximum value of $-2 \mu \mathrm{mol} / \mathrm{m}^{2} / \mathrm{s}$. This decrease is attributed to the leaf dehiscence of deciduous vegetation in the study area. A shift in the peak $\mathrm{CO}_{2}$ assimilation time is observed (figure 2a), i.e., from 1100-1200 hrs in
November and December to 1200-1400 hrs during January-May. This may be due to certain codominant (sub-storey) species (eg., Miliusa tomentosa) which remain green during the entire year. Average $\mathrm{CO}_{2}$ assimilation (positive flux for

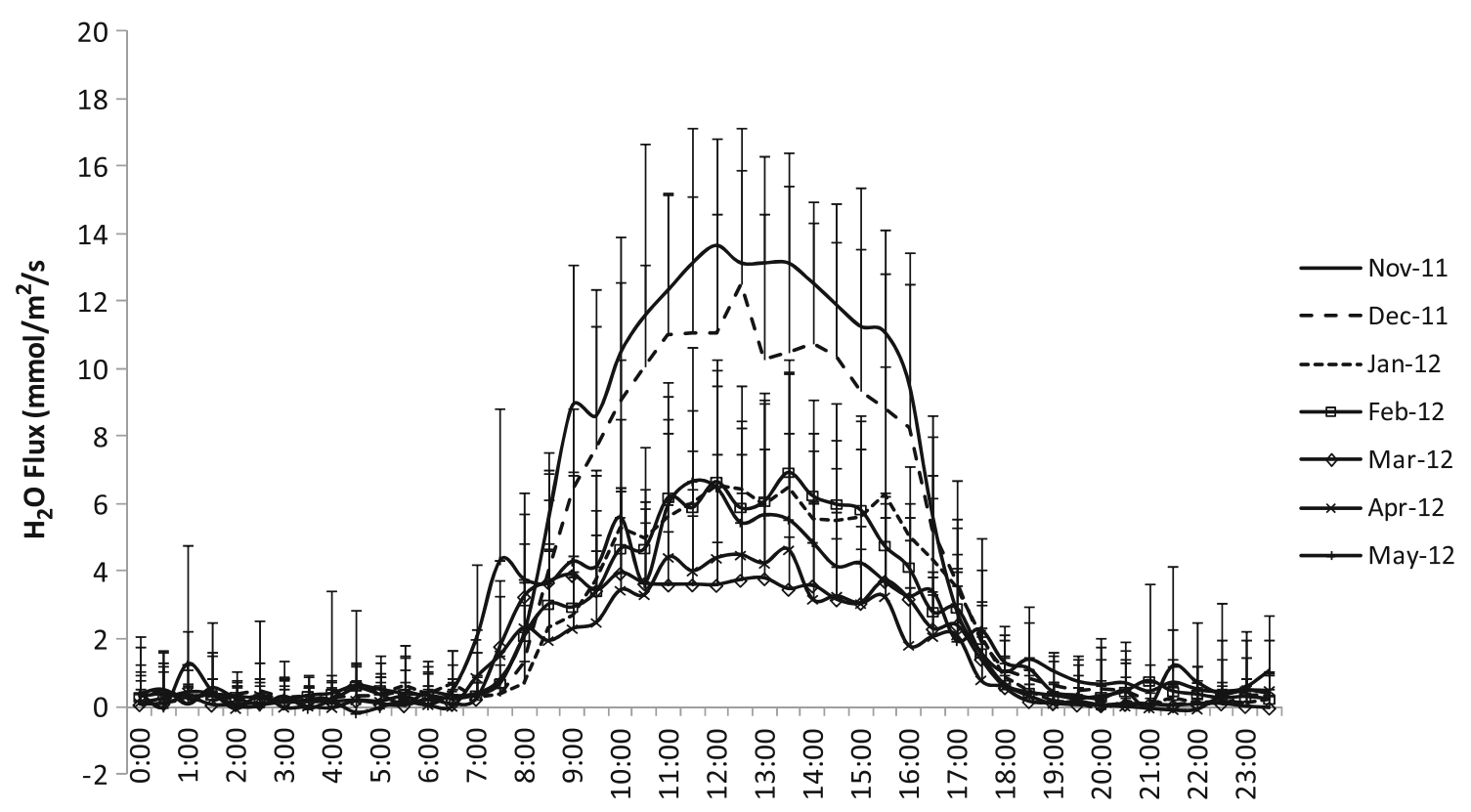

Time of the day (Hours)

Figure 3. Diurnal variations (monthly mean) in $\mathrm{H}_{2} \mathrm{O}$ flux with \pm 1 standard deviation.

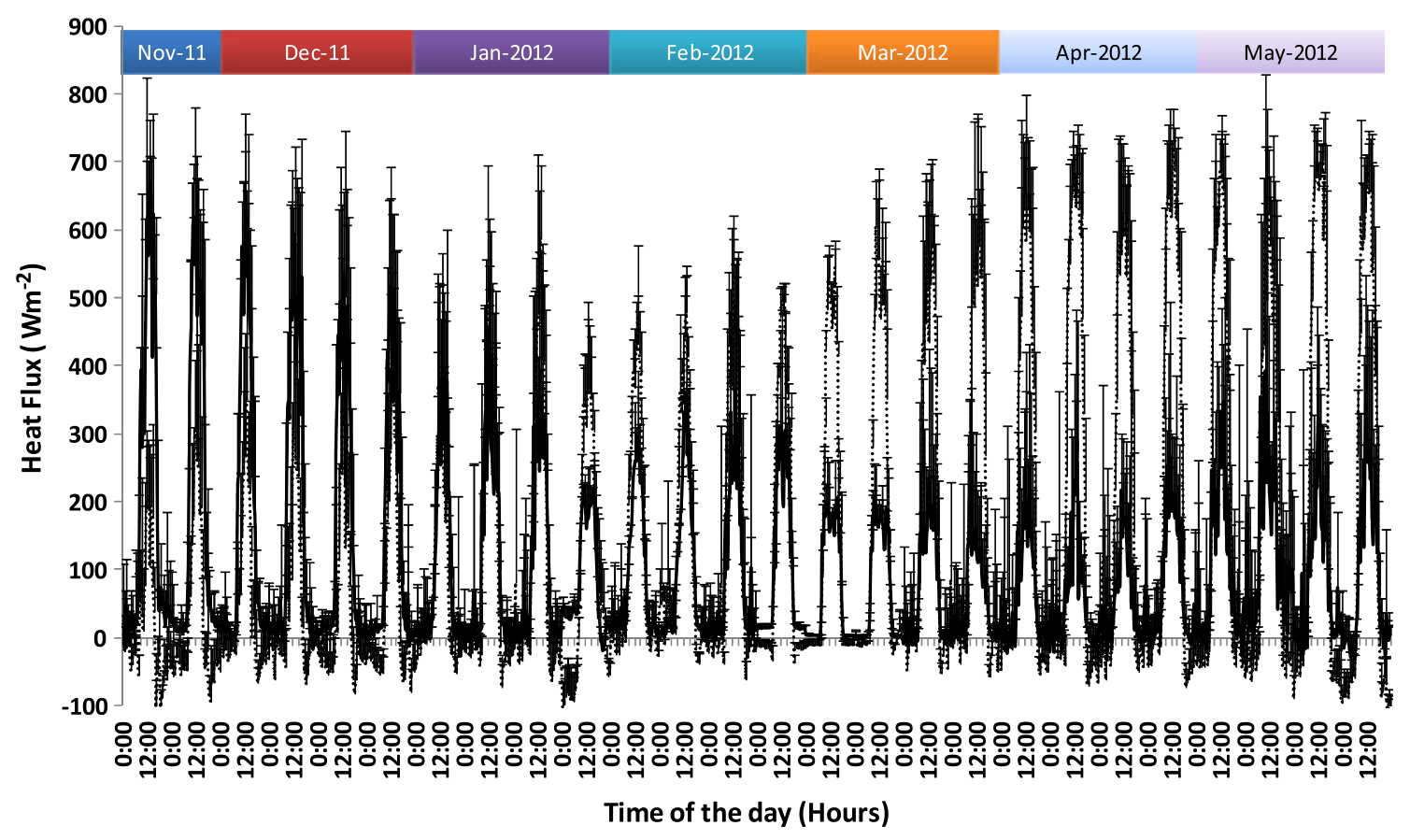

— Latent Heat …….. Sensible Heat

Figure 4. Latent and sensible heat flux variations (weekly mean) from November 2011 to May 2012 with \pm 1 standard deviation. 
photosynthesis) of the study area is relatively on the higher side compared to $\mathrm{CO}_{2}$ flux of temperate deciduous forests $\left(\sim-18 \mu \mathrm{mol} / \mathrm{m}^{2} / \mathrm{s}\right)$ reported by Goulden et al. (1996); Greco and Baldocchi (1996) and Saigusa et al. (2002).

Figure 3 shows monthly averaged diurnal variations of $\mathrm{H}_{2} \mathrm{O}$ flux across the study period. Peak flux values of water vapour $\left(15-20 \mathrm{mmol} / \mathrm{m}^{2} / \mathrm{s}\right.$ during winter season to less than $5 \mathrm{mmol} / \mathrm{m}^{2} / \mathrm{s}$ during dry period) are observed during mid-day (1100-1500 hrs) owing to the canopy level peak transpiration during noon. As the dry season progressed during March-May, the water vapour flux decreased which can be attributed to the leaflessness in the study area.

Figure 4 shows seasonal variations (weekly mean) in sensible and latent heat fluxes. Diurnal variations of latent heat and sensible heat fluxes showed a linear relationship with incoming solar radiation with peaks during mid-day. Energy partitioning between latent heat and sensible heat fluxes across the seasons suggested more heat being partitioned into latent heat flux (maximum weekly mean of $668 \mathrm{~W} / \mathrm{m}^{2}$ ) during winter season compared to low values of sensible heat flux (maximum weekly mean of $335 \mathrm{~W} / \mathrm{m}^{2}$ ).
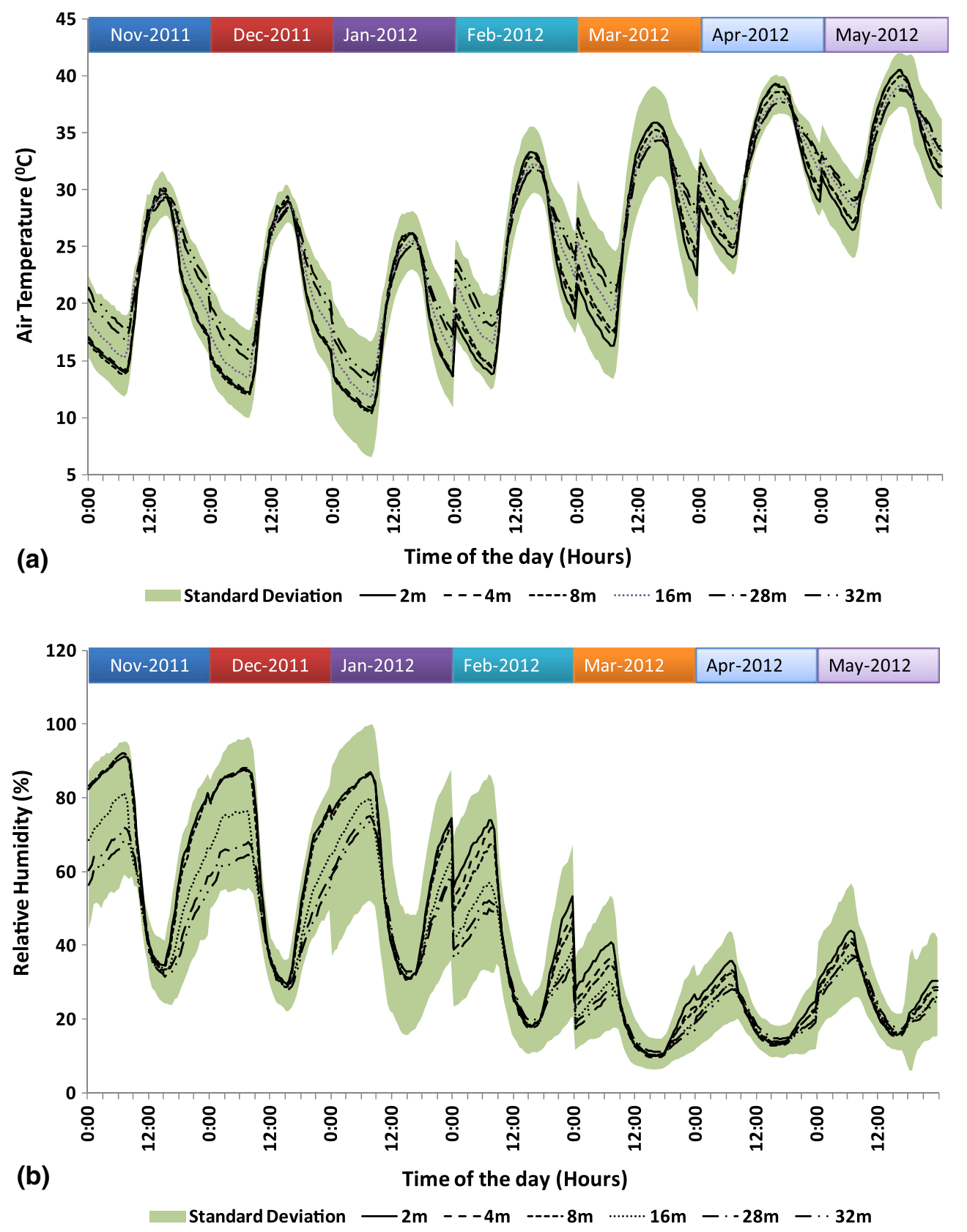

Figure 5. (a) Air temperature variations (monthly mean) from November 2011-May 2012 with \pm 1 standard deviation and (b) relative humidity variations (monthly mean) from November 2011-May 2012 with \pm 1 standard deviation. 
This is attributed to the dominance of canopy level transpiration associated with presence of peak leaf stage. Almost an inverse trend was observed during the dry season as the sensible heat maximum weekly mean of $718 \mathrm{~W} / \mathrm{m}^{2}$ dominated over the latent heat flux with maximum weekly mean of $410 \mathrm{~W} / \mathrm{m}^{2}$. Both latent and
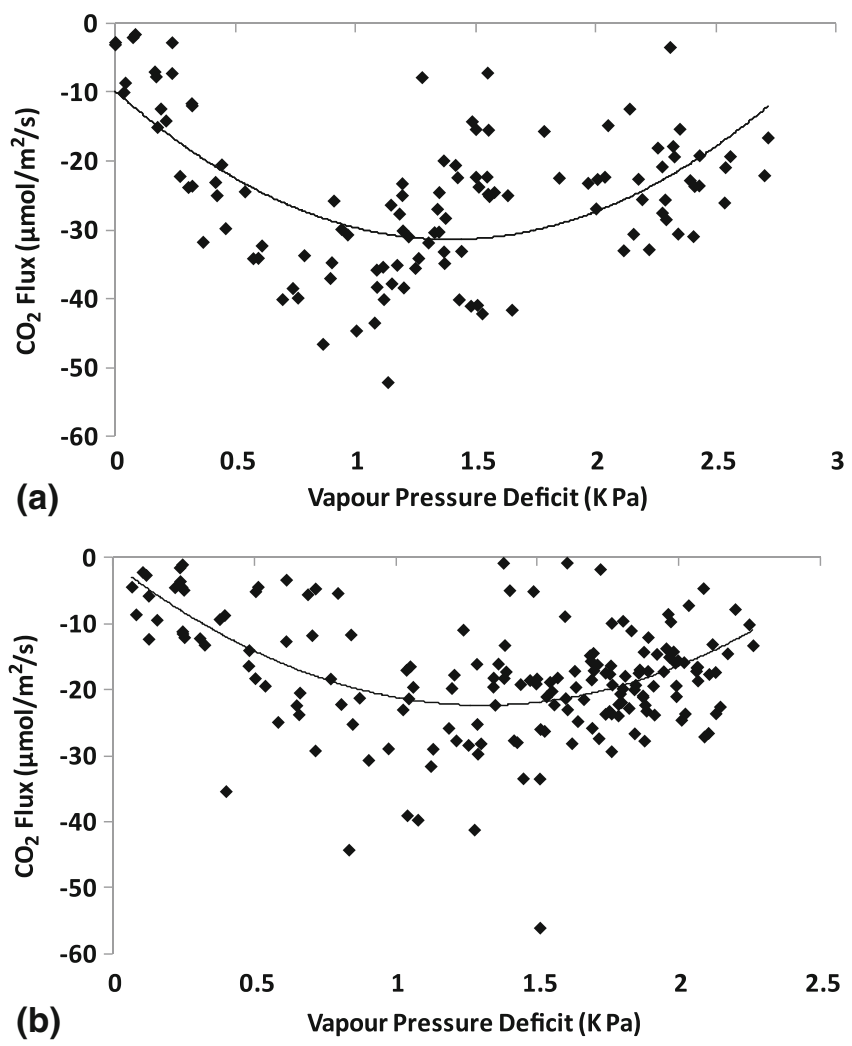

Figure 6. (a) Relationship between VPD and $\mathrm{CO}_{2}$ flux during 0800-1500 hrs local time - November and (b) relationship between VPD and $\mathrm{CO}_{2}$ flux during 0800-1500 hrs local time - December. sensible heat fluxes showed diurnal peaks during 1200-1300 hours across the seasons in positive correlation with high solar radiation during noon hours. Figure 5(a and b) shows seasonal variability in air temperature and relative humidity at 6 levels (table 2) at the study site respectively. Average air temperature in the study area (figure 5a) increased from $<15^{\circ} \mathrm{C}$ during winter season to as much as $35^{\circ} \mathrm{C}$ during dry months, while relative humidity (figure 5b) decreased from $\sim 80 \%$ to $30 \%$ as the summer season progressed. Diurnal variability of air temperature (figure 5a) showed that air temperature above the canopy ( $28 \mathrm{~m}$ and $32 \mathrm{~m}$ ) was relatively low compared to the below canopy levels during day hours, which is attributed to removal of heat by vegetation for transpiration. Inversely, above canopy temperatures are high compared to the below canopy levels during nighttime because of heat energy given out during respiration. Diurnal variability of relative humidity (figure $5 \mathrm{~b}$ ) showed high levels of moisture content above the canopy level during day hours because of water vapour release during transpiration, while an inverse trend is found during night hours. Seasonal pattern in air temperature and relative humidity showed that the variability in air temperature and relative humidity at the 6 levels which was quite discreet during winter (leaf) season, showed very less difference during summer (leafless) season, which is attributed to the modulation of the two weather parameters due to the regulation by the dense vegetation.

Vapour Pressure Deficit (VPD) which is the difference between saturated vapour pressure and actual vapour pressure is a key parameter and influences leaf level stomatal interactions with atmosphere. We attempted to analyse the relationship of VPD with $\mathrm{CO}_{2}$ and latent heat flux. We

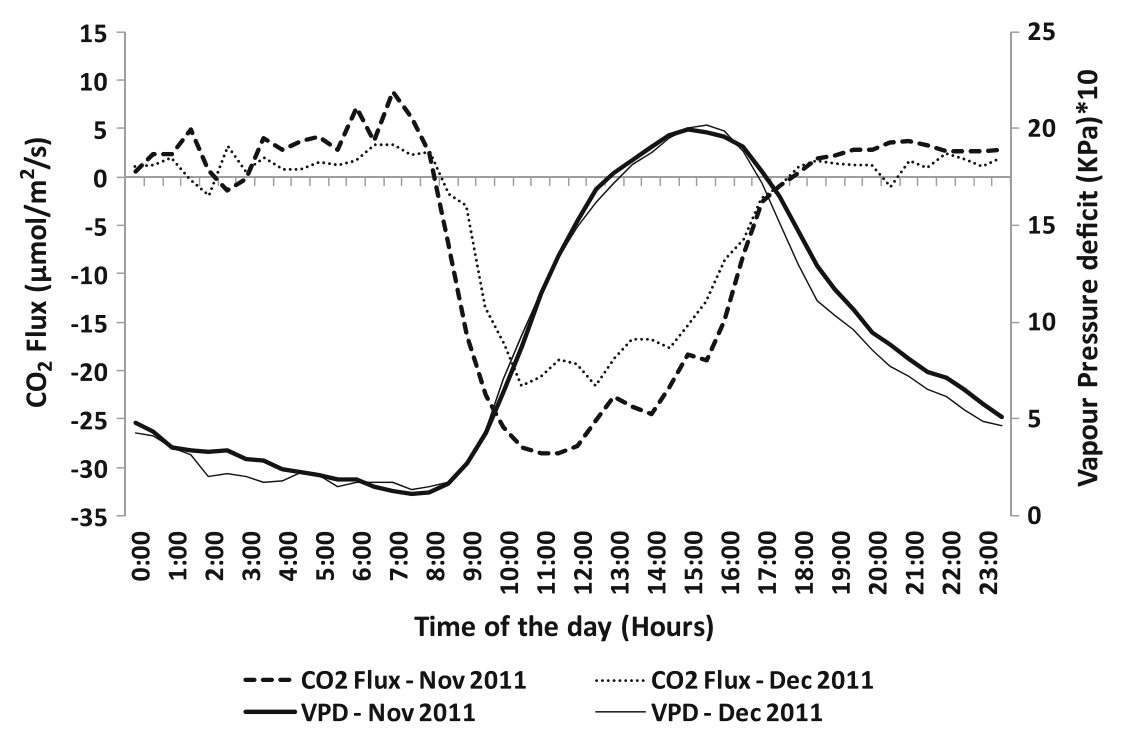

Figure 7. Relationship between VPD and $\mathrm{CO}_{2}$ flux (monthly mean). 
have analysed only for the active day hours (0800 to 1500 hrs during which more $\mathrm{CO}_{2}$ is sequestered for photosynthesis) and further only for winter season only so as to avoid leafless condition during summer. Figure $6(\mathrm{a}$ and $\mathrm{b})$ shows relationship between VPD and $\mathrm{CO}_{2}$ flux during 0800 to 1500 hrs for November and December, respectively. It is inferred from the figures that more $\mathrm{CO}_{2}$ is assimilated for photosynthesis up to VPD values of $<0.7 \mathrm{KPa}$ and afterwards limiting the $\mathrm{CO}_{2}$ assimilation with higher levels of VPD $>1 \mathrm{KPa}$. Similar relationship was observed between $\mathrm{CO}_{2}$ assimilation and latent heat with $\mathrm{CO}_{2}$ assimilation increasing with VPD up to $1 \mathrm{KPa}$ and thereby decreasing for higher values. The evaporation from leaf surfaces is proportional to the gradient of vapour pressure between the stomatal cavities and the air. However, for higher values of VPD, the leaf stomata partially close in order to maintain constant flow of water within the water level availability and to restrict any further loss of water as observed in figure 7. Similar observations were recorded elsewhere (Mahrt and Dean 2002).

\section{Conclusions}

In the present paper, initial results of eddy flux tower measurements for winter and summer seasons over teak-mixed deciduous forests of central Indian region are reported and analysed for the first time. The eddy flux tower is the first one in a natural ecosystem in the Indian region to be registered in the global flux community through AsiaFlux. Wet and dry season variations of $\mathrm{CO}_{2}$, $\mathrm{H}_{2} \mathrm{O}$ and heat fluxes during November 2011 to May 2012 were continuously measured using eddy flux tower and analysed in relation to the atmospheric variables over the study area and presented. The vegetation acted as $\mathrm{CO}_{2}$ sink during the winter season while very less $\mathrm{CO}_{2}$ fixation was observed during the dry months. Analysis on heat flux partitioning inferred that more energy has been partitioned into latent heat flux because of the transpiration process of leaves during winter season, while the sensible heat flux dominated during leafless summer season. Vegetation of the study area showed positive correlation with the availability of PAR during noon hours for photosynthetic activity, but subsequently modulated by higher values of VPD towards post-noon. With further establishment of flux towers in the representative ecosystems through ISRO network, we expect to generate a robust and climate quality database on greenhouse gas and energy flux for the respective ecosystems.

\section{Acknowledgements}

The present study is carried out as part of the National Carbon Project, funded by ISROGeosphere Biosphere Programme (ISRO-GBP). The authors duly acknowledge the logistic support and necessary permissions extended by the Madhya Pradesh Forest Department, Madhya Pradesh, India. They acknowledge the efforts of Shri K V Raghavendra, Scientist, NRSC, for software and hardware integration support of the flux tower. They also acknowledge, Dr S P S Kushwaha, Scientist, Indian Institute of Remote Sensing (IIRS, ISRO) for his initial support in the establishment of the flux tower.

\section{References}

Anderson D E and Verma S B 1986 Carbon dioxide, water vapour and sensible heat exchanges of a grain sorghum canopy; Bound.-Layer Meteorol. 34 317-331.

Baldocchi D D, Hicks B B and Meyers T P 1988 Measuring biosphere atmosphere exchanges of biologically related gases with micrometeorological methods; Ecol. 69 1331-1340.

Baldocchi D D, Falge $\mathrm{E}$ and $\mathrm{Gu}$ L 2001 FLUXNET: A new tool to study the temporal and spatial variability of ecosystem-scale carbon dioxide, water vapour and energy flux densities; Bull. Am. Meteor. Soc. 82 2415-2434.

Burba G and Anderson D 2007 Introduction to the eddy covariance method: General guidelines and conventional workflow; LI-COR Biosciences, Lincoln, USA, Electronic Edition, 141p.

Canadell J, Mooney $\mathrm{H}$ and Baldocchi D 2000 Carbon metabolism of the terrestrial biosphere; Ecosystem $\mathbf{3}$ $115-130$.

Clark D A, Brown S and Kicklighter D W 2001 Measuring net primary production in forests: Concepts and field measurements; Ecol. Appl. 11 356-370.

Collatz G J, Ball J T and Grivet C 1991 Regulation of stomatal conductance and transpiration: A physiological model of canopy processes; Agric. For. Meteor. 54 107-136.

Denmead O T, Dunin F X and Wong S C 1993 Measuring water use efficiency of Eucalpyt trees with chambers and micrometeorological techniques; J. Hydrol. 150 649-664.

Desjardins R L 1985 Carbon dioxide budget of maize; Agric. For. Meteor. 36 29-41.

Desjardins R L and Lemon E R 1974 Limitations of an eddy covariance technique for the determination of the carbon dioxide and sensible heat fluxes; Bound.-Layer Meteorol. 5 475-488.

Fan S M, Wofsy S C and Bakwin P S 1990 Atmosphere biosphere exchange of $\mathrm{CO}_{2}$ and $\mathrm{O}_{3}$ in the central Amazon forest; J. Geophys. Res. 95 16,851-16,864.

Field C B, Berry J A and Mooney H A 1982 A portable system for measuring carbon dioxide and water vapour exchanges of leaves; Plant Cell Environ. 5 179-186.

Garrity S R, Gil Bohrer, Maurer K D, Mueller K L, Vogel C S and Curtis P S 2011 A comparison of multiple phenology data sources for estimating seasonal transitions in deciduous forest carbon exchange; Agric. For. Meteor. 151 1741-1752. 
Geider R J, Delucia E H and Falkowski P G 2001 Primary productivity of planet earth: Biological determinants and physical constraints in terrestrial and aquatic habitats; Global Change Biol. 7 849-882.

Gonsamo A, Chen J M, Wu C and Dragoni D 2012 Predicting deciduous forest carbon uptake phenology by upscaling FluxNet measurements using remote sensing data; Agric. For. Meteor. 165 127-135.

Goulden M L, Munger J W, Fan S-M, Daube B C and Wofsy S C 1996 Measurements of carbon sequestration by long-term eddy covariance: Method and a critical evaluation of accuracy; Global Change Biol. 2 169-182.

Greco S and Baldocchi D D 1996 Seasonal variations of $\mathrm{CO}_{2}$ and water vapour exchange rates over a temperate deciduous forest; Global Change Biol. 2 183-197.

Ito A, Saigusa N, Murayama S and Yamamoto S 2005 Modelling of gross and net carbon dioxide exchange over a cool-temperate deciduous broad-leaved forest in Japan: Analysis of seasonal and interannual change; Agric. For. Meteor. 134 122-134.

Jenkins J P, Richardson A D, Braswell B H, Ollinger S V, Hollinger D Y and Smith M-L 2007 Refining light-use efficiency calculations for a deciduous forest canopy using simultaneous tower-based carbon flux and radiometric measurement; Agric. For. Meteor. 143 64-79.

Kim J and Verma S B 1990 Carbon dioxide exchange in a temperate grassland ecosystem; Bound.-Layer Meteorol. 52 135-149.

Mahrt L and Dean V 2002 Relationship of area-averaged carbon dioxide and water vapour fluxes to atmospheric variables; Agric. For. Meteor. 112 195-202.

Ohtaki E 1984 Application of an infrared carbon dioxide and humidity instrument to studies of turbulent transport; Bound.-Layer Meteorol. 29 85-107.
Oliphant A J, Grimmond C S B, Zutter H N, Schmid H P, $\mathrm{Su} \mathrm{H} \mathrm{B,} \mathrm{Scott} \mathrm{S} \mathrm{L,} \mathrm{Offerle} \mathrm{B,} \mathrm{Randolph} \mathrm{J} \mathrm{C} \mathrm{and}$ Ehman J 2004 Heat storage and energy balance fluxes for a temperate deciduous forest; Agric. For. Meteor. 126 185-201.

Running S W, Baldocchi D D and Turner D 1999 A global terrestrial monitoring network, scaling tower fluxes with ecosystem modeling and EOS satellite data; Remote Sens. Environ. 70 108-127.

Saigusa N, Yamamoto S, Murayama S, Kondo $\mathrm{H}$ and Nishimura N 2002 Gross primary production and net ecosystem exchange of a cool-temperate deciduous forest estimated by the eddy covariance method; Agric. For. Meteor. 112 203-215.

Schmid H P 1994 Source areas for scalars and scalar fluxes; Bound.-Layer Meteorol. 67 293-318.

Verma S B 1990 Micrometeorological methods for measuring surface fluxes of mass and energy; Remote Sens. Rev. $\mathbf{5}$ 99-115.

Verma S B, Baldocchi D D and Anderson D E 1986 Eddy fluxes of $\mathrm{CO}_{2}$, water vapour, and sensible heat over a deciduous forest; Bound.-Layer Meteorol. 36 71-91.

Verma S B, Kim J and Clement R J 1989 Carbon dioxide, water vapour and sensible heat fluxes over a tall grass prairie; Bound.-Layer Meteorol. 46 53-67.

Wesely M L, Cook D R and Hart R L 1983 Fluxes of gases and particles above a deciduous forest in wintertime; Bound.-Layer Meteorol. 27 237-255.

Wilson K B and Baldocchi D D 2000 Seasonal and interannual variability of energy fluxes over a broadleaved temperate deciduous forest in North America; Agric. For. Meteor. 100 1-18.

Wofsy S C, Goulden M L and Munger J W 1993 Net exchange of $\mathrm{CO}_{2}$ in a mid-latitude forest; Sci. $\mathbf{2 6 0}$ 1314-1317. 